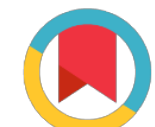

Check for updates

*For correspondence:

mokry@Ifhk.cuni.cz

Competing interests: The authors declare that no competing interests exist.

Received: 2017-06-26 Accepted: 2017-07-15

Published: 2017-09-05

Copyright The Author(s) 2017. This article is published with open access by BioMedPress (BMP).

This article is distributed under the terms of the Creative Commons Attribution License (CC-BY 4.0) which permits any use, distribution, and reproduction in any medium, provided the original author(s) and the source are credited.

\section{Acellular muscle scaffolds: Histological and biochemical evaluation}

\author{
Jaroslav Mokry, Hana Hrebíková, Jana Chvátalová, Rishikaysh Pisal, \\ Stanislav Filip, Govindan Dayanithi
}

Department of Histology and Embryology, Charles University in Prague, Medical Faculty Simkova 870, Hradec Kralove 50003, Czech Republic

\begin{abstract}
Anterior tibial muscle of $\mathrm{C}_{57} \mathrm{~B} / 6 / \mathrm{J}$ mice was subjected to decellularization with hypotonic solution, detergents and DNase. Resulting acellular scaffolds were examined to characterize the content of chromatin, cell cytoplasm and extracellular matrix components incl. basal laminas, fibres and glycoproteins. Although the sarcoplasm and cell nuclei were removed, the general skeletal muscle microarchitecture with ECM of stromal components remained well preserved at light and electron microscopic levels. Moreover, basal laminas contouring honeycomb-like structures left after removal of myofibres and vascular endothelium remained intact. Immunostaining of scaffolds for collagen IV and laminin confirmed positivity of basal laminas. Histochemical staining of deparaffinised scaffold sections identified well organized fibres after staining with green trichrome, Sirius red, Weigert's resorcin fuchsin and Gomori impregnation. Chemical analysis gave evidence of reduced dsDNA and well-preserved collagen according to high hydroxyproline content and laminin as documented by Western blotting. We cultured scaffolds seeded with murine myogenic cells in vitro and confirmed their cytocompatibility as the cells were able to adhere, grow and migrate through the ECM without affecting the scaffold structure. Myogenic cells were able to migrate in the endomysium and start to fuse. Implantation of decellularized scaffolds into an artificial cavity inside of anterior tibial muscle of mice in vivo confirmed the scaffolds were colonized soon by recipient inflammatory cells without formation of foreign body giant cells. Scaffolds were well integrated with recipient skeletal muscle and gradually resorbed within 3 weeks. Our results confirm decellularized muscle scaffold is a promising alternative for rebuilding the skeletal muscle organ as it can preserve basic chemical components and the tissue microstructure and show biocompatibility for myogenic cells as demonstrated in vitro and in vivo.
\end{abstract}

\section{Keywords}

Decellularized scaffold, ECM, skeletal muscle

Funding

GACR No 15-09161S and PROGES Q40/06

References 